\title{
Comparative Effect of Replacement of Canola Meal with Moringa oleifera Leaf Meal (MOLM) on Hemato-chemical Profile in Broilers
}

\author{
Hafeez Ur Rehman', Sultan Mahmood ${ }^{1}$, Fawwad Ahmad ${ }^{1}$, Mirza Muhammad Aslam, \\ Ghulam Abbas $^{2, *}$, Aisha Mahmood ${ }^{3}$, Muhammad Sajid ${ }^{4}$ \\ ${ }^{1}$ Institute of Animal and Dairy Sciences, University of Agriculture Faisalabad, Pakistan \\ ${ }^{2}$ Department of Animal Production, Riphah College of Veterinary Sciences, Lahore, Pakistan \\ ${ }^{3}$ Institute of Pharmacy, Physiology and Pharmacology, University of Agriculture, Faisalabad, Pakistan \\ ${ }^{4}$ Department of Anatomy, Riphah College of Veterinary Sciences Lahore, Pakistan
}

Copyright@2018 by authors, all rights reserved. Authors agree that this article remains permanently open access under the terms of the Creative Commons Attribution License 4.0 International License

\begin{abstract}
The present research was conducted to evaluate the effect of replacing canola meal with Moringa oleifera leaf meal on hemato-chemical properties in broilers. For this purpose, one hundred fifty, chicks were randomly distributed into five equal groups of 30 chicks each. These chicks were further sub-divided into three replicates in such a way that each replicate contained ten chicks. These chicks were randomly allotted to five treatment rations. Five isoproteinious (CP 21\%) and isocaloric (2900 Kcal $/ \mathrm{Kg}$ ) rations (A, B, C, D, and E) were formulated. Ration A contained $8 \%$ canola meal but without Moringa oleifera leaf meal and served as a control, whereas in rations $\mathrm{B}, \mathrm{C}, \mathrm{D}$ and $\mathrm{E}$ the canola meal was replaced by Moringa oleifera leaf meal (MOLM) @ 25, 50, 75 and $100 \%$ (w/w) of its total concentration (8\%). These rations were fed ad libitum from 8 to 42 days of age. At the end of trial, blood samples $(5 \mathrm{ml}$ each) from 3 birds/replicate were collected in sterilized disposable syringes. The serum was analyzed for the determination of blood glucose, cholesterol and liver function tests i.e. AST, ALT and ALP. The data collected were analyzed using Analysis of Variance (ANOVA) technique under Completely Randomized Design (CRD). Results revealed that the values of blood glucose, total cholesterol, ALT, AST and ALP were lowest in group E while these values were the highest in control group A. However, all these values were found within the normal range. It was concluded that replacement of canola meal with MOLM in broiler ration exhibited a significant $(\mathrm{P}<0.05)$ effect on hemato-chemical properties in broiler.
\end{abstract}

Keywords Broiler, Moringa oleifera, Canola, Glucose, Cholesterol

\section{Introduction}

Poultry industry is one of the largest industries of Pakistan and has shown tremendous growth during the last four decades. It has a major share of $1.12 \%$ in GDP of Pakistan and is a source of income for almost 1.5 million people. This sector has shown growth rate of $15-20 \%$ per annum and is a very good source of animal protein in the form of eggs and meat. Meat obtained from poultry is of fine quality and contributes $24.8 \%$ of total meat production in the country [3]. Human population is increasing day by day and feeding competition between human and animals is also mounting. Moreover, main ingredients used in animal feeds especially poultry feed are also being used for human consumption leading to decreased availability of quality feed resources, leading to high costs of poultry feeds. Therefore, increase in the prices of poultry feed ingredients especially vegetable protein sources is posing a serious threat to net return from a poultry business. In the current scenario it is difficult to formulate a least cost ration having good quality protein. However, use of non-conventional, easily available and economical feed ingredients can solve this problem. Hence, it is the need of time to explore the potential of non-conventional protein sources to reduce the cost of poultry ration as it constitutes 65 to $70 \%$ of total production cost. Therefore, prospect for the use of non-conventional cheaper protein sources like lucerne (Medicago sativa), neem (Azadirachta indica) and moringa leaves provide a great opportunity to economize the cost of poultry rations [18].

Moringa is a non-conventional vegetable protein source and can be used in poultry rations replacing canola meal [15]. Moringa has also been reported as hypo-cholesterolaemic [17], hypertensive [10], 
anti-ulcerative [23], diuretic and anti-inflammatory agent [25]. All these activities help in efficient functioning of liver in the body of broilers, which is a vital visceral organ in the bird that plays a pivotal role in different metabolic functions in the body like digestion, removal of waste products along worn-out cells from blood stream. It is also responsible for nutrient detoxification (neutralises toxins), protein synthesis and bile production which aids fat digestion and removes toxins through the bowels [16]. However, most of the times performance of liver is compromised because of exposure to several factors like therapeutic or sub-therapeutic levels of different medicines those cause liver injures [8].

Disease of liver is a worldwide problem and different hepato-protective drugs are used for the cure of liver problems although sometimes these have serious adverse side effects. Therefore, it is the necessity of time to find alternative hepato-protector to replace currently used conventional drugs to ensure efficacy and safety [22]. However, we do not have a suitable liver tonic to cure serious liver diseases of birds. However, medicinal plants [neem, garlic(Allium sativum), ginger (Zingiber officinale), kalongi (Nigella sativa), turmeric (Curcuma longa)savory (Satureja), mint (Mentha), chicory; kasni (Cichorium intybus) and Moringa oileifera are known to have positive impact on treatment of numerous liver disorders and most of the herbal drugs showed good economic returns to the poultry enterprise. These circumstances have compelled poultry scientists to the addition of non-conventional medicinal plants in poultry rations to overcome liver disorders [6].

Keeping in view the hypoprotective and hypo-cholesterolaemic properties of moringa tree, it can be envisaged that moringa leaf meal may prove a very good non-conventional source of plant medicine to be used as liver tonic as well as a good protein source in poultry diets, to combat liver problems and high prices of poultry feeds. Moreover, information regarding digestibility and hemato-chemical properties of Moringa oleifera leaf meal in poultry feed is limited, which otherwise can help to explain improvement in performance parameter of birds due to its inclusion in poultry diet. Based upon the information/discussion above, present study has been planned to investigate the effects of replacing canola meal with Moringa oleifera leaf meal on hemato-chemical properties in broilers.

\section{Materials and Methods}

The research study was conducted at Poultry Research Center, University of Agriculture, Faisalabad.

\section{Experimental Birds}

For the research project, two hundred twenty, day old broiler chicks (Hubbard) were purchased from local hatchery and reared on a commercial broiler starter feed for one week (adaptation period). After one week, all the chicks were individually weighed and one hundred fifty chicks of middle weight range were selected and randomly distributed into five equal groups of 30 chicks each. These chicks were further sub-divided into three replicates in such a way that each replicate contained ten chicks.

\section{Preparation of Moringa oleifera Leaves Meal}

Moringa oleifera leaves were collected from an orchard maintained by the Department of Crop Physiology, University of Agriculture, Faisalabad. Branches of Moringa oleifera were cut off from the trees and were brought in to the laboratory of Department of Poultry Science, for the preparation of leaf meal. Leaves from the branches were separated and spread on a polythene sheet. These leaves were dried in the laboratory (under shade) for a period of five days. The dried leaves were ground and the material thus obtained was designated as Moringa oleifera leaf meal (MOLM). The leaf meal was stored in plastic bags till utilized in the preparation of experimental rations.

\section{Experimental Rations and their Feeding Plan}

Five experimental rations (A, B, C, D, and E) were prepared with or without MOLM by replacing, $0,25,50$, 75 and $100 \%$ canola meal. These rations were isoproteinous (21\%) and isocaloric (2900 Kcal/ kg). Ration A contained canola meal (8\%) but without any addition of moringa leaf meal in it and served as a control. Whereas in ration B, C, D and E canola meal was replaced with Moringa oleifera leaf meal (MOLM) @ 25\%,50\%,75\% and $100 \%$, respectively. These rations were fed ad libitum to the experimental birds from day 8 to 42 days of age. A weighed amount of the rations was offered to the birds twice a day (early morning and late evening) and the left over feed was collected to calculate feed consumption of the birds. The detail of the experimental rations, groups and feeding plan are as under.

\begin{tabular}{|c|c|}
\hline Groups & Treatments \\
\hline $\begin{array}{c}\text { Group A } \\
\text { (Control) }\end{array}$ & Ration without MOLM but having 8\% canola meal \\
\hline Group B & $25 \%$ canola meal was replaced by MOLM \\
\hline Group C & $50 \%$ canola meal was replaced by MOLM \\
\hline Group D & $75 \%$ canola meal was replaced by MOLM \\
\hline Group E & $100 \%$ canola meal was replaced by MOLM \\
\hline
\end{tabular}

The birds in each replicate were reared in separate pens measuring $3 \mathrm{ft} \times 4 \mathrm{ft}$ (12 sq.ft). These experimental pens were thoroughly cleaned, washed, white washed, disinfected and fumigated prior to arrival of chicks. The chicks were reared under same managemental conditions like temperature, ventilation, relative humidity, floor space and light. Fresh and clean water were available all the time to the birds. These birds were vaccinated against New 
Castle Disease (ND) and Infectious Bursal Disease (IBD).

Biological Classification of Moringa oleifera

\begin{tabular}{|c|c|c|c|}
\hline Kingdom & Plantae (Plants) & Subclass & Dilleniidae \\
\hline $\begin{array}{c}\text { Sub } \\
\text { kingdom }\end{array}$ & $\begin{array}{c}\text { Tracheobionta } \\
\text { (Vascular plants) }\end{array}$ & Order & Capparales \\
\hline $\begin{array}{c}\text { Super } \\
\text { division }\end{array}$ & $\begin{array}{c}\text { Spermatophyta } \\
\text { (Seed plants) }\end{array}$ & Family & $\begin{array}{c}\text { Moringaceae } \\
\text { (Horse-radish tree } \\
\text { family) }\end{array}$ \\
\hline Division & $\begin{array}{c}\text { Magnoliophyta } \\
\text { (Flowering plants) }\end{array}$ & Genus & $\begin{array}{c}\text { Moringa } \\
\text { Adans.(Moringa) }\end{array}$ \\
\hline Class & $\begin{array}{c}\text { Magnoliopsida } \\
\text { (Dicotyledons) }\end{array}$ & Species & $\begin{array}{c}\text { Moringa oleifera } \\
\text { Lam. (Horseradish } \\
\text { tree) }\end{array}$ \\
\hline
\end{tabular}

Biological classification of canola

\begin{tabular}{|c|c|}
\hline Kingdom & Plantae \\
\hline Order & Brassicales \\
\hline Family & Brassicaceae \\
\hline Genus & Brassica \\
\hline Species & B. napus \\
\hline Binomial name & Brassica napus \\
\hline
\end{tabular}

Amino acid profile of canola meal $35 \%$ crude protein basisaccording to NRC, 2001

\begin{tabular}{|c|c|c|c|}
\hline lysin & $\mathbf{0 . 7 7}$ & Methionin & $\mathbf{0 . 7 7}$ \\
\hline Isoleucine & 1.14 & Valine & 1.74 \\
\hline cystin & $\mathbf{0 . 9 4}$ & proline & $\mathbf{2 . 3}$ \\
\hline phenylalanine & $\mathbf{1 . 5 4}$ & Glysin & $\mathbf{1 . 7 5}$ \\
\hline Tyrosine & $\mathbf{1 . 0 5}$ & Alanine & $\mathbf{1 . 5 3}$ \\
\hline Histidine & $\mathbf{1 . 1 3}$ & Threonine & $\mathbf{1 . 5 0}$ \\
\hline Serine & 1.64 & Arginine & 2.03 \\
\hline Tryptophan & 0.64 & & \\
\hline
\end{tabular}

At the end of trial, blood samples (5ml each) from 3 birds/replicate were collected in sterilized disposable syringes. These blood samples were used for serum collection in sterilized serum cups. The cups containing the serum were freezed till analyzed for the determination of blood glucose, cholesterol and liver function tests i.e. AST, ALT and ALP by using standard kit (Biomega) method in biochemistry analyzer (Tecno-786). The data collected were analyzed using Analysis of Variance (ANOVA) technique under Completely Randomized Design (CRD). Means were partitioned by Least Significant Difference (LSD) test.

\section{Results and Discussion}

Mean values regarding serum metabolites i.e. glucose, total cholesterol level, Alanine Aminotransferase (ALT), Aspartate Aminotransferase (AST) and Alpha GlutamylTransferase (ALP) of broilers fed Moringa oleifera leaf meal replacing canola meal are shown in Table 1.

Analysis of variance of data revealed that addition of different level of Moringa oleifera leaf meal exhibited significant $(\mathrm{P}<0.05)$ effect on blood glucose levels of the birds of all treatment groups as compared to control group. The results of the study revealed maximum decrease in blood glucose level in the birds of treatment group E fed ration in which $100 \%$ canola meal was replaced with Moringa oleifera leaf meal as compared to those of other treatment groups. Whereas significantly $(\mathrm{P}<0.05)$ higher level of blood glucose was observed in the birds of group A (control) which were fed 0\% Moringa oleifera leaf meal supplemented diet as compared to other treatment groups. However, blood glucose levels of the birds in treatment groups C (50\% MOLM), D (75\% MOLM) and E (100\% MOLM) were found to be non-significant among each other.

Moringa oleifera leaf meal reduced blood glucose levels when used as replacement of canola meal. This might be due to the presence of flavonoids and terpenoids in MOLM as has been reported by various researchers [21] that flavonoids and secondary plant metabolites (arginine and glutamic acid) possess hypoglycemic properties in different animal prototypes. It has also been reported that terpenoids present in Moringa oleifera leaf meal also have stimulatory impact on ß-cells, followed by insulin secretion which ultimately reduce blood glucose level. Similar results have been observed by Ghebreselassie et al. [9] in mice fed different level of Moringa stenopetala leaves extract.

Table 1. Effect of replacing canola meal with Moringa oleifera leaf meal on blood hemato-chemical mean values of serum metabolites (glucose, cholesterol) and Liver function (ALT, AST and ALP) test of broilers

\begin{tabular}{|c|c|c|c|c|c|c|}
\hline \multirow[b]{2}{*}{ Variables } & \multicolumn{5}{|c|}{ Treatments } & \multirow{2}{*}{$\begin{array}{l}\text { Pooled } \\
\text { S.E }\end{array}$} \\
\hline & $\begin{array}{c}\text { A } \\
\text { Control }\end{array}$ & $\begin{array}{c}\text { B } \\
25 \% \text { MOLM } \\
\end{array}$ & $\begin{array}{c}\text { C } \\
50 \% \text { MOLM }\end{array}$ & $\begin{array}{c}\text { D } \\
75 \% \text { MOLM }\end{array}$ & $\begin{array}{c}\text { E } \\
100 \% \text { MOLM } \\
\end{array}$ & \\
\hline Blood Glucose(mg/dl) & $228.50^{a}$ & $169.63^{b}$ & $163.67^{\mathrm{bc}}$ & $142.13^{\mathrm{bc}}$ & $106.33^{\mathrm{c}}$ & 10.641 \\
\hline Total Cholesterol (mg/dl) & $268.00^{\mathrm{a}}$ & $236.83^{b}$ & $241.50^{b}$ & $227.17^{\mathrm{b}}$ & $221.00^{\mathrm{b}}$ & 5.079 \\
\hline $\begin{array}{c}\text { ALT-Alanine } \\
\text { Aminotransferase (U/L) }\end{array}$ & 68.00 & 58.00 & 56.92 & 53.00 & 50.83 & 5.163 \\
\hline $\begin{array}{c}\text { AST-Aspartate } \\
\text { Aminotransferase (U/L) }\end{array}$ & $68.33^{\mathrm{a}}$ & $57.50^{\mathrm{a}}$ & $40.33^{b}$ & $35.83^{b}$ & $35.33^{b}$ & 2.804 \\
\hline $\begin{array}{c}\text { ALP-Alpha } \\
\text { Glutamyltransferase (U/L) }\end{array}$ & $35.50^{\mathrm{a}}$ & $25.50^{\mathrm{b}}$ & $21.17^{\mathrm{b}}$ & $19.17^{\mathrm{b}}$ & $18.33^{\mathrm{b}}$ & 1.983 \\
\hline
\end{tabular}

Values within the same row which have different superscripts are significantly different $(\mathrm{P}<0.05)$ 
Analysis of variance of data showed that inclusion of Moringa oleifera leaf meal in place of canola meal showed significant $(\mathrm{P}<0.05)$ effects on total cholesterol of the birds of all treatment groups as compared to control group. The results of the study showed significantly $(\mathrm{P}<0.05)$ decreased level of total cholesterol in the birds of treatment group E (100\% MOLM) followed by those of group D (75\% MOLM), C (50\% MOLM) and B (25\% MOLM), respectively, as compared to control group. Whereas significantly $(\mathrm{P}<0.05)$ higher level of total cholesterol was observed in birds of group A (control) which were fed $0 \%$ MOLM in ration, when compared to other treatment groups. However, total cholesterol level of the birds in treatment groups B (25\% MOLM), C (50\% MOLM), D (75\% MOLM) and $\mathrm{E}$ (100\% MOLM) was found to be non-significant among each other.

Replacement of canola meal with Moringa oleifera leaf meal resulted in decreased serum cholesterol level of experimental birds. This decline might be due to hypo-cholestrolemic properties present in Moringa oleifera leaf meal. Mehta et al. [17] reported fruits and leaves of Moringa oleifera showed hypo-lipidemic properties when fed to rabbits, resulting in reduction of phospholipid, cholesterol, LDL, VDL and cholesterol to phospholipid ratio. This might be due to increased activity of extra hepatic lipoprotein lipase which circulates lipoprotein and efficiently do the lipolysis of triglycerides in skeletal muscle, heart and adipose tissue [26].Similar results have been observed by Jaiswal et al. [11] who found decrease in the blood cholesterol level in rats fed different levels aqueous extract of Moringa oleifera's leaves.

Liver function test (LFT) of serum was comprised of three enzymes i.e. Alanine Aminotransferase (ALT), Aspartate Aminotransferase (AST)and Alpha GlutamylTransferase (ALP), which are the most sensitive biochemical markers employed in the diagnosis of hepatic dysfunction due to the misuse of antibiotics as a growth promotive agents in broiler production [12].

Analysis of variance of data revealed that addition of various levels of Moringa oleifera leaf meal did not exhibit any significant $(\mathrm{P}<0.05)$ effect on ALT concentration in birds of all treatment groups. However, apparently numerical values of ALT concentration were found to be the lowest in the birds fed diet in which canola meal was $100 \%$ replaced with MOLM, followed by those of treatment groups D (75\% MOLM), C (50\% MOLM) and B (25\% MOLM), whereas the highest numerical value of ALT was observed in control group (0\% MOLM). Similar findings have been observed by Adedapo et al. [1] who found decreasing trend of values of ALT concentration in rats fed different level of aqueous extract of Moringa oleifera in their ration.

Analysis of variance of data revealed that replacement of canola meal with Moringa oleifera leaf meal exhibited significant $(\mathrm{P}<0.05)$ effect on AST concentration in the birds of groups treated with MOLM as compared to those of control group. The results of the study revealed significant $(\mathrm{P}<0.05)$ reduction in the concentration of AST in the birds of treatment group $\mathrm{E}$ in which canola meal was replaced with $100 \%$ Moringa oleifera leaf meal among the treatment groups. Whereas significantly $(\mathrm{P}<0.05)$ higher concentration of AST was observed in the birds of group A (control) which were fed 0\% Moringa oleifera leaf meal in the diet. However, AST concentration in the birds of treatment groups B (25\% MOLM), C (50\% MOLM), D (75\% MOLM) and E (100\% MOLM) were found to be non-significant among each other.

Replacement of canola meal with Moringa oleifera leaf meal exhibited a significantly $(\mathrm{P}<0.05)$ reduced AST concentration in the experimental birds. These findings are compatible with those observed by Gunjal et al. (2010), who reported a significant decrease in AST concentration of Wistar rats treated with aqueous extract of Moringa oleifera lam stem bark. These findings are also in line with the findings of Fakurazi et al. [7], Kumar and Pari [14], Nadro et al. [19] and Das [5] who also reported significant decrease in concentration of AST in mice.

Analysis of variance of data exhibited that inclusion of Moringa oleifera leaf meal replacing canola meal exhibited significant $(\mathrm{P}<0.05)$ effect on ALP concentration in the birds of groups fed diets containing Moringa oleifera leaf meal as compared to control group. The results of the study revealed significant $(P<0.05)$ reduction in ALP concentration of in the birds of treatment group $\mathrm{E}$ $(100 \%$ MOLM) followed by those in group D (75\% MOLM), C (50\% MOLM) and D (25\% MOLM).

Whereas significantly $(\mathrm{P}<0.05)$ higher concentration of ALP was observed in the birds of group A (control)which were fed diet containing canola meal but without the addition of Moringa oleifera leaf meal when compared to other treatment groups. However, ALP concentration in the birds of treatment groups B (25\% MOLM), C (50\% MOLM), D (75\% MOLM) and E (100\% MOLM) was found to be non-significant among each other. Canola meal replacement by MOLM resulted in decreased ALP level of blood. This might be due to preservation of liver histology procured by different levels of Moringa oleifera leaf meal. Ruckmani et al. [24] reported flowers and roots of Moringa oleifera decreased the level of ALP in rats. It was further stated that process of normalization and recovery of enzyme with the addition of MOLM suggested that MOLM played some role in preserving structural integrity of hepato-cellular membrane, thus preventing enzymes leakage into the blood circulation. These results are in compatible with those observed by Ahmed and Khater(2001) who reported that transaminase level reduced to normal with restoration of hepatic parenchyma and the regeneration of hepatocytes [19]. The other possible reason of hepatoprotective action might be the presence of natural antioxidant in MOLM like ascorbic acid, rutin and quercetin as these hepatoprotective properties of MOLM have been found by Kanteret al.[13].

Conclusion: Inclusion of Moringa oleifera leaf meal (MOLM) in the rations revealed better hemato-chemical 
properties of broilers than canola meal. Therefore, use of

as a hepatoprotective, inexpensive and equally efficient Moringa oleifera leaf meal in broilers diet is recommended

source of plant protein in place of canola meal.

\section{Appendix}

Table 2. Composition of experimental rations

\begin{tabular}{|c|c|c|c|c|c|}
\hline \multirow{3}{*}{ Ingredients } & \multicolumn{5}{|c|}{ Experimental Rations } \\
\hline & A & B & C & D & E \\
\hline & 0\% MOLM & 25\% MOLM & $50 \%$ MOLM & 75\% MOLM & 100\% MOLM \\
\hline Corn & 34 & 34 & 34 & 34 & 34 \\
\hline Wheat & 13 & 13 & 13 & 12 & 12 \\
\hline Rice broken & 10 & 10 & 10 & 10 & 10 \\
\hline Sorghum & 3 & 3 & 3 & 3 & 3 \\
\hline Sunflower meal & 5 & 5 & 5 & 5 & 5 \\
\hline Corn gluten $60 \%$ & 5 & 5 & 5 & 5 & 5 \\
\hline Canola meal & 8 & 6 & 4 & 2 & 0 \\
\hline MOLM & 0 & 2 & 4 & 6 & 8 \\
\hline Soybean meal & 13.5 & 14 & 14.2 & 15 & 15.3 \\
\hline Fish meal & 5 & 5 & 5 & 5 & 5 \\
\hline Bone meal & 1.5 & 1 & 1 & 1 & 1 \\
\hline Salt & 0.5 & 0.5 & 0.3 & 0.2 & 0.2 \\
\hline Molasses & 0.5 & 0.5 & 0.5 & 0.8 & 0.5 \\
\hline Premix & 1 & 1 & 1 & 1 & 1 \\
\hline Total & 100 & 100 & 100 & 100 & 100 \\
\hline \multicolumn{6}{|c|}{ Chemical composition } \\
\hline Crude protein (\%) & 21.05 & 21.00 & 21.00 & 21.07 & 21.05 \\
\hline $\mathrm{ME} \mathrm{Kcal/kg}$ & 2908 & 2927 & 2927 & 2923 & 2908 \\
\hline
\end{tabular}

Table 3. Nutritional profile of Moringa oleifera

\begin{tabular}{|c|c|c|c|c|c|c|}
\hline 100 g of Edible portion & Water (\%) & ME (Calories) & Protein (g) & Fat (g) & Carbo-hydrate (g) & Fiber (g) \\
\hline Pods & 86.9 & 26 & 2.5 & 0.1 & 3.7 & 4.8 \\
\hline Leaves & 75.0 & 92 & 6.7 & 1.7 & 13.4 & 0.9 \\
\hline Leaf meal & 7.5 & 205 & 27.1 & 2.3 & 38.2 & 19.2 \\
\hline
\end{tabular}

(Anonymous, 1998)

Table 4. Minerals composition in Moringa oleifera

\begin{tabular}{|c|c|c|c|c|c|c|c|}
\hline 100 g of Edible portion & Ca $(\mathrm{mg})$ & $\mathrm{Mg}(\mathrm{mg})$ & $\mathrm{P}(\mathrm{mg})$ & $\mathrm{K}(\mathrm{mg})$ & $\mathrm{Cu}(\mathrm{mg})$ & $\mathrm{Fe}(\mathrm{mg})$ & $\mathrm{S}(\mathrm{g})$ \\
\hline Pods & 30 & 24 & 110 & 259 & 3.1 & 28.2 & 137 \\
\hline Leaves & 440 & 25 & 70 & 259 & 1.1 & 7 & 137 \\
\hline Leaf powder & 2003 & 368 & 204 & 1324 & 0.057 & 5.3 & 870 \\
\hline
\end{tabular}

(Ayssiwede, 2011)

Table 5.Amino acid composition in Moringa oleifera

\begin{tabular}{|c|c|c|c|c|c|c|c|c|}
\hline $\begin{array}{c}100 \text { grams } \\
\text { of Edible } \\
\text { portion }\end{array}$ & $\begin{array}{c}\text { Arginine } \\
(\mathrm{g} / 16 \mathrm{gN})\end{array}$ & $\begin{array}{c}\text { Histidine } \\
(\mathrm{g} / 16 \mathrm{gN})\end{array}$ & Lysine(g/16gN) & $\begin{array}{c}\text { Tryptoph-an } \\
(\mathrm{g} / 16 \mathrm{gN})\end{array}$ & $\begin{array}{c}\text { Phenylanaline } \\
(\mathrm{g} / 16 \mathrm{gN})\end{array}$ & $\begin{array}{c}\text { Methionine } \\
(\mathrm{g} / 16 \mathrm{gN})\end{array}$ & $\begin{array}{c}\text { Threonine } \\
(\mathrm{g} / 16 \mathrm{gN})\end{array}$ & $\begin{array}{c}\text { Leucine } \\
(\mathrm{g} / 16 \mathrm{~g})\end{array}$ \\
\hline Pods & 3.6 & 1.1 & 1.5 & 0.8 & 4.3 & 1.4 & 3.9 & 6.5 \\
\hline Leaves & 6.0 & 2.1 & 4.3 & 1.9 & 6.4 & 2.0 & 4.9 & 9.3 \\
\hline $\begin{array}{c}\text { Leaf } \\
\text { powder }\end{array}$ & $1.33 \%$ & $0.61 \%$ & $1.32 \%$ & $0.43 \%$ & $1.39 \%$ & $0.35 \%$ & $1.19 \%$ & $1.95 \%$ \\
\hline
\end{tabular}


Table 6. Vitamin composition in Moringa oleifera

\begin{tabular}{|c|c|c|c|c|c|c|c|}
\hline $\begin{array}{c}100 \text { grams of } \\
\text { Edible portion }\end{array}$ & $\begin{array}{c}\text { Vitamin A - } \\
\text { Beta Carotene } \\
(\mathrm{mg})\end{array}$ & $\begin{array}{c}\text { Vitamin B- } \\
\text { Choline (mg) }\end{array}$ & $\begin{array}{c}\text { Vitamin B1 - } \\
\text { Thiamin (mg) }\end{array}$ & $\begin{array}{c}\text { Vitamin B2 - } \\
\text { Riboflavin } \\
(\mathrm{mg})\end{array}$ & $\begin{array}{c}\text { Vitamin B3 - } \\
\text { Nicotinic acid } \\
(\mathrm{mg})\end{array}$ & $\begin{array}{c}\text { Vitamin C - } \\
\text { Ascorbicacid } \\
\text { (mg) }\end{array}$ & $\begin{array}{c}\text { Vitamin E - } \\
\text { Tocopherol } \\
\text { acetate }\end{array}$ \\
\hline Pods & 0.11 & 423 & 0.05 & 0.07 & 0.2 & 17.3 & - \\
\hline Leaves & 6.8 & 423 & 0.21 & 0.05 & 0.8 & 220 & - \\
\hline Leaf powder & 16.3 & - & 2.64 & 20.5 & 8.2 & 120 & 113 \\
\hline
\end{tabular}

Table 7. Nutritional profile of canola meal

\begin{tabular}{|c|c|}
\hline Nutrients & Average value \\
\hline Moisture (\%) & 10.0 \\
\hline Crude protein ( $\mathrm{N}$ x 6.25\%) & 35.0 \\
\hline Metabolize able energy (kcal/kg) & 2000 \\
\hline Oil (\%) & 3.5 \\
\hline Linoleic acid (\%) & 0.6 \\
\hline Ash & 6.1 \\
\hline Crude fibre (\%) & 12.0 \\
\hline Tannins (\%) & 1.5 \\
\hline Sinapine (\%) & 1.0 \\
\hline Phytic acid (\%) & 4.0 \\
\hline Glucosinolates ( $\mu$ moles/g) & 16 \\
\hline Calcium (\%) & 0.63 \\
\hline Phosphorus (\%) & 1.08 \\
\hline Available P (\%) & $0.3-0.5$ \\
\hline Sodium (\%) & 0.10 \\
\hline Chlorine (\%) & 0.10 \\
\hline Potassium (\%) & 1.22 \\
\hline Sulphur (\%) & 0.85 \\
\hline Magnesium (\%) & 0.54 \\
\hline Copper (mg/kg) & 5.8 \\
\hline $\operatorname{Iron}(\mathrm{mg} / \mathrm{kg})$ & 166 \\
\hline Manganese (mg/kg) & 52 \\
\hline Zinc (mg/kg) & 58 \\
\hline Selenium (mg/kg) & 1.1 \\
\hline
\end{tabular}

\section{REFERENCES}

[1] Adedapo, A. A., O. M. Mogbojuri and B. O. Emikpe. 2009. Safety evaluations of the aqueous extract of the leaves of Moringa oleifera in rats. J. Med. Plants Res. 3: 586-591.

[2] Anonymous. 1998. Analysis of leaf powder for nutritional composition. URL. http/www.moringafarms.com (accessed on August 1, 2012).

[3] Anonymous. 2010-11. Pakistan Economic Survey, Planning and Development Division, Govt. Pak. istan, Isd. 34-35.

[4] Ayssiwede, S.B., J.C. Zanmenou, Y. Issa, M. B. Hane, A. Dieng, C. A. A. M. Chrysostome, M. R. Houinato, J. L.
Hornick and A. Missohou. 2011. Nutrient composition of some unconventional and local feed resources available in Senegal and recoverable in indigenous chickens or animal feeding. Pak. J. Nutri. 10: 707- 717.

[5] Das, N., K. Sikder, S. Ghosh, B. Fromenty and S. Dev. 2012. Moringa oleifera Lam. leaf extract prevents early liver injury and restores antioxidant status in mice fed with high-fat diet. Ind. J. of Exp. Biol. 50: 404-412.

[6] Fahey, J. W., A. T. Dinkova-Kostova and P. Talalay. 2004. The "Prochaska" microtiter plate bioassay for inducers of NQO1. Chapter 14 in Methods Enzymology. 382 (part B): 243-258.

[7] Fakurazi, S., I. Hairuszahand U. Nanthin. 2008. Moringa oleifera Lam prevents acetaminophen induced liver injury through restoration of glutathione level. Food and Chem. Toxico. 46: 2611-2615. 
[8] Gagliano, N., F. Grizzi and G. Annoni. 2007. Mechanism of aging and liver functions. Digest. Dis. Sci. 25: 118-123.

[9] Ghebreselassie, D., Y. Mekonnen, G. Gebru, W. Ergete and K. Huruy. 2011. The effects of Moringa stenopetala on blood parameters and histopathology of liver and kidney in mice. Ethiop. J. Health. 25: 53-57.

[10] Gilani, A. H., K. Aftab, A. Suria, S. Siddiqui, R. Saleem, B. S. Siddiqui and S. Faizi. 1994. Pharmacological studies on hypotensive and spasmolytic activities of pure compounds from Moringa oleifera. Phytotherapy Research. 8: 87-91.

[11] Jaiswal, D., P. K. Rai, A. Kumar, S. Mehta and G. Watal. 2009. Effect of Moringa leifera Lam. leaves aqueous extract therapy on hyperglycemic rats. J. Ethnopharmacology. 123: 392-396

[12] Johnkennedy, N., E. Adamma, A. Austin and N. N. E. Chukwunyere. 2010. Alterations in biochemical parameters of wister rats administered with sulfadoxine and pyrimethamine (Fansidar-R). Al Ameen J. Med. Sci. 3: 317-321.

[13] Kanter, M. 2010. Protective effect of quercetin on liver damage induced by biliary obstruction in rats. J. Mol. Histol. 41: 395.

[14] Kumar, N. A. and L. Pari. 2003. Antioxidant Action of Moringa oleifera Lam. (Drumstick) Against Antitubercular Drugs Induced Lipid Peroxidation in Rats. J. Medicinal Food. 6: 255-259.

[15] Liaqat, S. 2012. Effect of replacement of canola meal with Moringa oleifera leaf meal on blood hematology, immune response and performance of broilers. M.Sc. Hons. Thesis, Department of Poultry Science. University of Agriculture, Faisalabad.

[16] Maton, A., H. Jean, C.W. McLaughlin, M.Q. Warner, D. Lattart and J. D. Wright. 1993. Human Biology and Health. Eaglewood Cliffs, New Jersey, Prentice Hall, USA.

[17] Mehta, K., R. Balaraman, A. H. Amin, P. A. Bafna and O. D.
Gulati. 2003. Effect of fruits of Moringa oleiferaon the lipid profile of normal and hypercholesterolemic rabbits. J. Ethnopharmacol. 86: 191-195.

[18] Muriu, J. I., E. N. Njoka-Njiri, J. N. Tuitoek and J. N. Nanua. 2002. Evaluation of sorghum as replacement of maize in the diet of growing rabbits. J. Anim. Sci. 15: 565-569.

[19] Nadro, M.S., Arungbemi, R. M. and D. Dahiru. 2006. Evaluation of Moringa oleifera Leaf Extract on Alcohol-induced Hepatotoxicity. Tropi. J. Pharma. Res. 5: 539544.

[20] NRC. 2001. Nutrient requirements of dairy cattle. 7th Rev. Ed., National Acad. Press, Washington, D. C.

[21] Ojowole, J. O. A., 2002. Hypoglycemic effect of Clausena anisata (Willd) hook methanolic root extract in rats. J. Ethnopharmacol. 81: 231-237.

[22] Ozbek, H. S., I. Ugras, I. U. Bayram and E. Erdogan. 2004. Hepatoprotective effect of Foeniculum vulgare essential oil: A carbon tetrachloride induced liver fibrosis model in rats. Scand. J. Anim. Sci. 31: 9-17.

[23] Pal, S. K., P. K. Mukherjee and B. P. Saha. 1995. Studies on the antimicrobial action of the leaf extract of Moringa oleifera Lam. Ancient Science of Life. 14: 197-199.

[24] Ruckmani, K., S. Kavimani, R. Anandan and B. Jaykar. 1998. Effect of Moringa oleifera Lam on paracetamol-induced hepatoxicity. Ind. J. Pharm. Sci. 60: 33-35.

[25] Udupa, S.L. and A. L. Udupl. 1994. Studies on the anti-inflammatory and wound healing properties of Moringa oleifera and Aegle marmelos. Fitoterapia 65: 119-123.

[26] Yagyu, H., S. Ishibashi, Z. Chen, J. I. Osuga, M. Okazaki, S. Perrey, T. Kitamine, M. Shimada, K. Ohashi, K. Harada, F. Shionoiri, N. Yahagi, T. Gotoda, Y. Yazaki and Y. Yamada. 1999. Over expressed lipoprotein lipase protects against atherosclerosis in apolipoprotein E knockout mice. J. Lipid Res.40: 1677-1685. 